\title{
Customer Experience on Islamic Banking Digital Branch in Indonesia
}

\author{
Dwi Januar Luqmansyah ${ }^{1, *}$ Sri Rahayu Hijrah Hati, Ph.D ${ }^{2}$ \\ ${ }^{1}$ Master Management, Faculty of Economics and Business, University of Indonesia, Jakarta, Indonesia \\ ${ }^{2}$ Department of Management, Faculty of Economics and Business, University of Indonesia, Depok, Indonesia \\ *Corresponding author.Email:dluqmansyah@gmail.com
}

\begin{abstract}
As a country with the largest Muslim population in the world, Islamic banking in Indonesia also contributes to the national banking industry, although its market share is still limited. This requires Islamic banking to better understand the needs of its customers. One of the business process transformations carried out by banking today is changing traditional operational services to digital-based operational services. The first Islamic bank that carries the concept of Digital Branch is Mandiri Syariah. The purpose of this study was to determine the effect of customer experience on attitudes towards Islamic banking and contemporary marketing concepts such as customer satisfaction and loyalty. This study uses the online questionnaire for customers who make transactions at Digital Branch. With 25 research question items, this study managed to collect 252 service user respondents at three Digital Branch outlets. Data analysis using the PLS-SEM method, and the result is customer experience has a positive and significant effect on attitudes towards Islamic banking as well as customer satisfaction and loyalty. The study implies how frontline personnel factors most influence customer experience and customer experience has the greatest influence on attitude toward Islamic banking compared to satisfaction and loyalty on Islamic Bank Digital Branch in Indonesia. Most of them have the expectation of having a customer experience in accordance with sharia values which is expected to be better than conventional banking.
\end{abstract}

Keywords: Attitude towards Islamic Banking, Customer experience quality, Digital Branch, Islamic Banking, Loyalty, Satisfaction.

\section{INTRODUCTION}

Indonesia is a country with the biggest number of Muslims in the world, the condition of its Islamic financial industry is still in the 7th position from total assets after other countries according to State of the Global Islamic Economy 2020/21 Report [1]. As one of the players in the financial services industry today, Islamic banking also contributes to the banking industry in general and is no longer considered a business entity that only struggles to fulfils the religious obligations of Muslims, but as a business that must win the hearts of customers. This requires that Islamic banks be able to understand the expectations and perceptions of their customers towards them in terms of the quality of banking services and other factors to increase customer satisfaction and loyalty in making transactions. Therefore, in order for Islamic banks to compete with conventional banks, in addition to adopting Sharia compliance, product features and services must also be equipped with skill and capacity to integrate modern technology.

According to Financial Services Authority (OJK) data, as of June 2019, 189 Islamic financial institutions have operated, consisting of 164 Islamic public finance banks (BPRS), 20 Islamic business units (UUS) and 14
Islamic commercial banks (BUS). The current obstacle and challenge in Islamic banking is the low level of public literacy. Based on the 2019 OJK survey, only about $37.7 \%$ of Indonesia's population has financial awareness and understands financial products. About $76.2 \%$ have used financial products and opened bank accounts. The awareness and understanding of Islamic financial principles is even lower, namely around $8.9 \%$ and around $9.2 \%$ using sharia products and services. The sharia inclusion index fell from $11 \%$ to $9.2 \%$ in 2019. Islamic banking has consistently grown above the industry average. Even during the Covid-19 pandemic, Islamic banking was still survive in terms of growth in total assets, financing and deposits. However, the total assets of Islamic banking are still IDR 531 trillion, while conventional banking is IDR 8,670 trillion. So the total market share of Islamic banking is $6.13 \%$ of the total national banking sector (as of June 2020). During the pandemic, Islamic banking continued to grow positively at $9.22 \%$ [2].

Mandiri Syariah (now Bank Syariah Indonesia) on November 8, 2019 launched the first digital branch service in the ranks of Islamic banking [3]. Digital branch service is a transformation and improvement of Branch Office services that previously operated in the form of regular bank outlets. The concept of Digital 
branch is carried out through the modernisation of the banking hall with the appearance of a modern and clean building. As well as technology-based business processes, mainly through digitising forms with go green spirit by implementing paperless processes in services so that customers are expected to be more comfortable in transactions. With a cozy ambience like a cafe lounge, customers can make transactions themselves or be assisted by Customer Service and Tellers more comfortable [3].

\section{LITERATURE REVIEW}

\subsection{Customer Experience}

The development of marketing has changed. The economy continues to develop over time. Historically, economists have equated experience with service. Experience has recently been classified as a distinct economic supply. Because of this, the company has shifted their focus to provide a customer experience that is worth paying more. This illustrates changes in customer behaviour as well as organisational strategies that emphasise the customer value and firm relationship in addition to the intrinsic utility of the goods and services offered [4]. The industrial era 4.0 pushed for further changes. Internet changed relationship marketing from being database oriented to collaborative relationships with customers. According to $\mathrm{T}$. Fernandez \& T. Pinto, Customer Experience has 4 (four) measurement factors, namely environment, frontline personnel, moments of truth and product offerings [5].

\subsubsection{Environment}

One of the dimensions of customer experience which is identical to the tangible dimension refers to the physical environment [6], with the concept of a contemporary, open and modern branch office to provide customers with a positive emotional perception of the customer experience quality [7].

\subsubsection{Frontline Personel}

Frontline personnel are customer assessments of communications and interactions with employees at branches. Employee interpersonal skills have the potential to influence the customer experience so that they can create value and goal-oriented experiences in consumer behaviour [8].

\subsubsection{Moments of Truth}

The moment of truth is flexibility, especially when complaints or mistakes occur when dealing with customers [8]. Handling complaint, solving problems, providing best service, and keeping promises must be done by the Bank. This explains the effect of service provider behaviour on current and future customer decisions in the event of an accident [9].

\subsubsection{Product Offerings}

This dimension refers to core services, namely the reach and features of the bank's products and services, as well as customers' perceptions of having sufficient choices and information to assess them [10]. describes customer ratings of all interactions with service providers before, during, and after transactions are made.

\subsection{Attitude Towards Islamic Banking}

Banks that promise products and services like conventional banks, but also affirm adherence to Sharia principles, add value to their Muslim customers. This perception not only to the universalist or conformist customer, making religiosity less relevant in predicting Muslim consumer attitudes towards Islamic banking [11]. This dimension is specific and different from religiosity, namely measuring intrinsic and extrinsic beliefs and attitudes towards religion [12]. Therefore, attitudes towards Islamic or halal banking are a more relevant, specific and direct antecedent that can better predict consumer behaviour that compared with religiosity.

\subsection{Customer Satisfaction}

Satisfied customers will use the service even more in the future, and will say positive things to others existing customers or prospect customers. Customers evaluate the performance of products and services and compare them with their expectations [13]. Expectations reflect anticipated behaviour and a consequence of information from public communications or personal experiences with products or service providers.

\subsection{Customer Loyalty}

Customer loyalty is a consumer's attachment to services or other entities based on preferred behavioural responses [14]. This is very important to retain existing customers because first-time customers are more difficult to convince without experience with the services or goods offers. So, these brands need comprehensive marketing in order for them to buy [15]. In fact, loyal customers defend the institution and even invite other people and can recommend them to join with it. 


\subsection{Digital Branch}

The implementation of the first Digital Branch in Islamic banking is one of the strategic initiatives in meeting customer needs and responding challenges to compete in the national banking arena. In accordance with the opportunity statement, namely "Mandiri Syariah needs to strengthen the Modern image as an element of the 2020 vision, to become the Leading and Modern Sharia Bank" [3]. Based on the results of MarkPlus research in 2017, the public's perception of a Modern Bank is a technology-based bank. The purpose of implementing Digital Branch is to present a branch office that represents a Modern Bank. So the solution overview applied is the modernisation of the banking hall with pilot locations at the Jakarta Thamrin and Plaza Mandiri Branch Offices through a solution, namely the appearance of a modern building (banking hall interior) so that it is more comfortable and technology-based business processes primarily through digitising forms and providing self-service machine areas, so that the banking hall function is increased for cross selling consumer financing product (Griya, Oto, etc.), financing of Gold Investments and Hajj \& Umra needs [3].

\subsection{Research Hypothesis}

Based on the previous discussion, the researcher formulated a research hypothesis in looking at the relationship between customer experience quality and attitude toward Islamic banking, customer satisfaction and customer loyalty for the customer of Islamic bank digital branch services as follows:

Hypothesis 1: Customer experience quality has a positive influence on Attitude toward Islamic Banking for digital branch's customers.

The experience dimension has been referred to interchangeably, as the consumption experience, customer experience and service experience. Previous researchers approached customer experience from different perspectives, but complemented each other as processes, antecedents to other outputs or as phenomena. Thus, customers with the company can create their own experience and the company as a resource integrator to facilitate the formation of co creation. (Jain et al., 2017) [16].

Hypothesis 2: Attitude toward Islamic banking has a positive effect on customer satisfaction with digital branch's customers.

Certain religious attitudes and other factors that have causative relationship and have contributed to the patronisation of Islamic banks remain to be investigated. This relationship may occur because attitudes towards Islamic banking serve as a "halo effect" in customer perceptions of customer experience and overall satisfaction [17].

Hypothesis 3: Customer experience quality has a positive effect on customer satisfaction with digital branch's customers.

Taking samples from digital branch services at Mandiri Syariah banking transactions are carried out through customer service and tellers using e-forms and gadgets provided at the banking hall. Pleasure and happiness or consumption emotions are very good, have a positive impact on the evaluation of satisfaction [18]. A positive environment will increase the emotional effect which will increase the satisfaction score. Emotional value, which in this study is stated as fun activity, can also affect customer satisfaction, because it is a motivating force to encourage consumers to participate in joint production [7].

Hypothesis 4: Customer experience quality has a positive effect on customer loyalty of digital branch's customers.

Customer loyalty is a consumer's attachment to services or other entities based on preferred behavioural responses [14]. This is very important to retain existing customers because first-time customers are more difficult to convince without experience with the services or goods offers. So, these brands need comprehensive marketing in order for them to buy [15]. In fact, loyal customers defend the institution and even invite other people and can recommend them to join in it [19]. Therefore, loyal consumers can function as a "fantastic marketing force" for company. Loyal customers will require less cost to serve them, because some of the customers already know the product offerings and need less information [20].

Hypothesis 5: Customer satisfaction has a positive effect on customer loyalty of digital branch's customers.

From the researcher's perspective, system satisfaction is the level of customer satisfaction with the digital branch system as a form of service innovation. However, if the customer is not satisfied with the online on boarding experience in the digital branch, then this is likely to have a negative impact on customer satisfaction with the digital branch service. In measuring customer satisfaction, it will be known whether it affects customer loyalty. By maintaining loyalty, it will increase the willingness of customers to provide references, to pay for services at high prices, and spend and buy more products [21]. 


\section{RESEARCH METHODS}

In compiling this research, there are several important references in previous research that are used as references and modifications are made to obtain relevant research models. The first reference to customer experience is a research conducted by $\mathrm{T}$. Fernandez \& T. Pinto (2019) on "The role of customer experience: Relationship quality determinants and outcomes in retail banking services" then from Mohammad M Mohsin \& M Aftab (2013) which discusses "Incorporating attitude towards Halal banking in an integrated service quality, satisfaction and loyalty model in the online Islamic banking context". The two studies were adapted to measure customer experience quality which consists of 4 measurement dimensions, namely environment, frontline personnel, moments of truth and product offerings as a formative constructs that affect customer attitudes towards Islamic banking, especially digital branches that affect customer satisfaction related to customer loyalty.

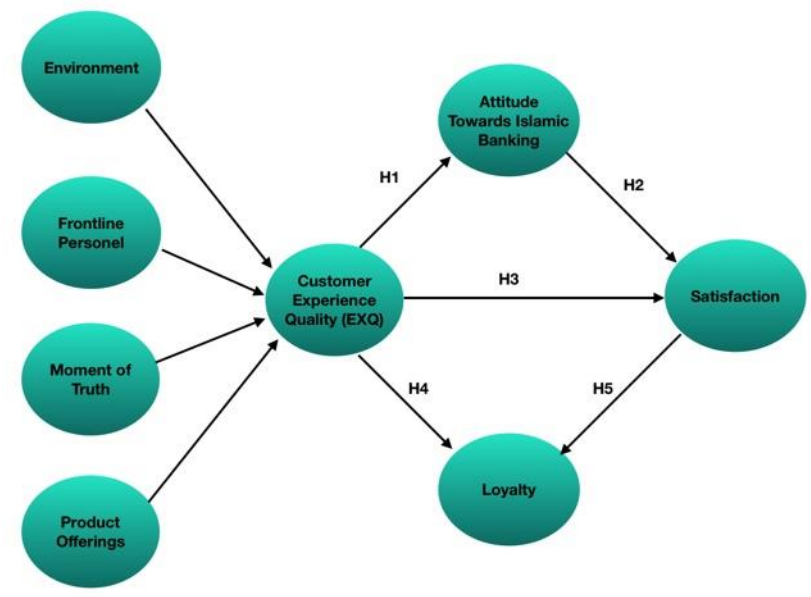

Figure 1. Research Model

\subsection{Data Collection}

The data collection technique uses a structured questionnaire as an instrument for collecting primary data which presents respondents with a set of fixed choices. The questionnaire will be sent via an online channel, then the researcher notifies and informs the opening page of the survey and asks them to participate after explaining the scope of the research. In general, respondents are willing to participate in research and answer questionnaires. The questionnaire will contain 25 questions and take about 3 to 5 minutes. Researchers will collect all answers and collect data and use the Structural Equation Model (SEM) tools.

\subsection{Population and Sample}

This research will be tested using the SEM method. In general, the sample size for structural equation modeling is at least 200 observations [22]. Meanwhile, the opinion of Hair, Aderson, Tatham and Black in Kusnaedi (2005) suggests that the minimum sample size for SEM analysis is 100 to 200 observations.

Population is total of all objects or individuals that have certain characteristics, which in this study are customers of the Digital Branch of Bank Syariah Mandiri. We will take samples from several customers who have experienced doing transactions at the branch and have the opportunity to fill out the survey given. Thus, the sample can represent the customer population as an object of research.

\subsection{Technical Data Analysis}

The questionnaire consists of two parts, namely questions about demographics and questions related to customer experiences in digital branch services. In the pretest, the researcher will test the validity. This is intended to see whether the measurement instruments will measure correctly [22]. And it is important to see whether the questionnaire is valid in measuring variables. Minimum respondents for validity testing are 30 respondents.

Research analysis using Structural Equation Modelling - Partial Least Squares (SEM_PLS) using SmartPLS 3.0 software. SEM-PLS is explicitly recommended for this research model, including the construction of formative measures and the ease of combining reflective and formative measures [22]. The data collection technique uses a structured questionnaire as an instrument for collecting primary data which presents respondents with a set of fixed choices.

\section{DATA ANALYSIS}

This study uses 25 scales of measurement items so that at least 5 times the sample size is required. Thus, based on these criteria a minimum of 125 respondents is required. Research use a minimum target of 200 respondents based on the criteria of the number of samples to tested using the SEM method. The data analysis in this study is based on research instruments that have been distributed by researchers to 252 respondents who have filled out the questionnaire. The results of the respondent profile can be seen in the table 1. Several parameters that must be measured on the outer model or commonly called a reflective measurement model.

Composite reliability values from 0.60 to 0.70 can be accepted in exploratory research, while in more advanced research stages, a value between 0.70 and 0.90 can be considered satisfactory. A value above 0.90 (and 
Table 1. Respondent Profile

\begin{tabular}{|c|c|c|}
\hline Parameter & Frequency & $\%$ \\
\hline \multicolumn{3}{|l|}{ Age } \\
\hline$<17$ & 1 & $0,4 \%$ \\
\hline $17-21$ & 20 & $7,9 \%$ \\
\hline $26-35$ & 146 & $57,9 \%$ \\
\hline $36-45$ & 64 & $25,4 \%$ \\
\hline $46-55$ & 20 & $7,9 \%$ \\
\hline$>56$ & 1 & $0,4 \%$ \\
\hline Total & 252 & $100 \%$ \\
\hline \multicolumn{3}{|l|}{ Gender } \\
\hline Female & 131 & $52 \%$ \\
\hline Male & 121 & $48 \%$ \\
\hline Total & 252 & $100 \%$ \\
\hline \multicolumn{3}{|l|}{ Occupation } \\
\hline Student & 16 & $6,3 \%$ \\
\hline Private employee & 139 & $55,2 \%$ \\
\hline Government employee & 17 & $6,7 \%$ \\
\hline BUMN employee & 51 & $20,2 \%$ \\
\hline Entrepreneurs & 11 & $4,4 \%$ \\
\hline Professional & 6 & $2,4 \%$ \\
\hline Housewife & 9 & $3,6 \%$ \\
\hline Others & 3 & $1,2 \%$ \\
\hline Total & 252 & $100 \%$ \\
\hline \multicolumn{3}{|l|}{ Education } \\
\hline Elementary School & 0 & $0 \%$ \\
\hline Junior High School & 0 & $0 \%$ \\
\hline Senior High School & 8 & $3,2 \%$ \\
\hline Diploma & 2 & $0,8 \%$ \\
\hline Graduate & 178 & $70,6 \%$ \\
\hline Post Graduate & 64 & $25,4 \%$ \\
\hline Total & 252,000 & $100 \%$ \\
\hline \multicolumn{3}{|l|}{ Religion } \\
\hline Islam & 217 & $86,1 \%$ \\
\hline Christians & 24 & $9,5 \%$ \\
\hline Catholics & 8 & $3,2 \%$ \\
\hline Hindu & 1 & $0,4 \%$ \\
\hline Budhist & 2 & $0,8 \%$ \\
\hline Total & 252,000 & $100 \%$ \\
\hline
\end{tabular}

definitely above 0.95 ) is undesirable because it implies that all indicator variables measure the same phenomenon and therefore are unlikely to be a valid construct measure [22]. The general rule used is that the outer loading value must be at least 0.709 or higher [23]. AVE (Average Variance Extracted) is used to evaluate convergent validity, the cut off value for AVE itself is 0.5 [23]. These three parameters can be seen in table 2 .

Next, what must be done is to test the inner model, which is to test the significance between the exogenous and endogenous variables, the parameters used are the
T-value and the p-value. Critical T-value is the cutoff value or criterion that determines the significance of the coefficient. The T-value used in this study is 1.645 , so that the hypothesis that has T-value of more than 1.645 can be declared significant and acceptable. The p-value is the probability that $\mathrm{H} 0$ will be rejected, $\mathrm{H} 1$ will be accepted. If the p-value is below 0.05 , there is a significance between the exogenous variables and the endogenous variables

With the PLS-SEM method, hypothesis testing is performed using a simulation using bootstrapping with 5000 subsamples. Bootstrapping is used to minimize the effect of data normality on research results. From the calculation results, the outer weight value shows that all indicators have a significant value with the highest value on the Attitude Towards Islamic Banking variable. In the second order construct, the highest value is the Frontline Personal variable (see Table 3).

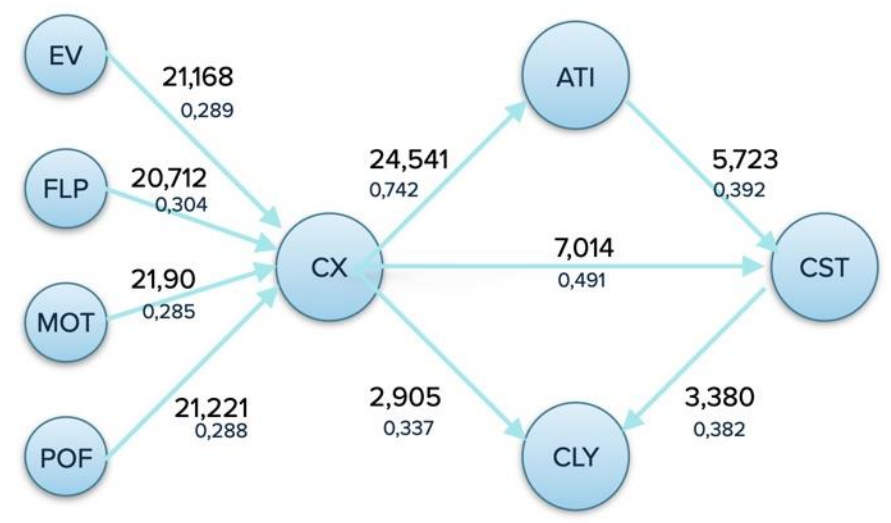

Figure 2. Research Model with Outer Weight and T Value

H1 testing is accepted. This is reflected in T-value that is greater than 1.645 , namely 24.541 and $\mathrm{P}$ value below 0,05. Mandiri Syariah customers mostly have hopes of experiencing a customer experience that is in accordance with sharia values. As previously stated, there may be a causative relationship to attitudes towards Islamic banking which can function as a "halo effect". This will provide the customer's perception of the customer experience and overall satisfaction with the banking service. [17].

$\mathrm{H} 2$ testing is accepted. This can be seen with Tvalue greater than 1.645, namely 5.723 and $P$ value below 0.05 . Banks that claim and can provide similar products and services to those offered by conventional banks, but also affirm adherence to Sharia principles, add value to customers who embrace the Islamic faith. Thus, when making transactions in accordance with the principles of Islamic finance, inner satisfaction will arise. The perception of customers that is formed regarding the suitability of banks with Islamic financial 
principles is one of the most important factors in supporting Islamic banks and building customer's trust.

H3 testing is accepted. This can be seen with Tvalue greater than 1.645, namely 7.014 and $P$ value below 0.05 . The dimension of customer experience consists of four dimension according to T. Fernandez \& T. Pinto 2019. Positive environment will increase the emotional effect which will increase the satisfaction score. Emotional value, which in this study is stated as fun activity, can also affect customer satisfaction, because it is a motivating force to encourage consumers to participate in joint production [7].

$\mathrm{H} 4$ testing is accepted. This can be seen with Tvalue greater than 1.645, namely 2.905 and $\mathrm{P}$ value of 0.004 which is still below 0.05 as the limit of the significance level. Based on this hypothesis it can be concluded that each interaction contributes to the customer's evaluation. The company has a role in being a facilitator to maximise the ability of customers to create optimal experiences [24]. With so many competitors in banking and the variety of product and program offerings, it is possible that customer loyalty is something that is challenging to maintain. So that even though customers are satisfied with a service, it is not certain that these customers will become loyal customers. Therefore, to win customers' hearts requires a strong attachment so that customers can continue to be maintained as loyal customers.

H5 testing is accepted. This can be seen from Tvalue which is 3.390 and the $P$ value of 0.001 which is still below 0.05 . Satisfaction can be analogized as an after-use evaluation of the quality of the service provided before service expectations and the conceptual framework found in expectations-disconfirmation theory [25]. This also applies to the Digital Branch Mandiri Syariah service, which priorities customer centricity in meeting customer needs. In accordance with the results of MarkPlus research in 2017, the public's perception of a Modern Bank is a technologybased bank. 
Table 2. Measurement scales, reliability and dimensionality statistics

\begin{tabular}{|c|c|c|c|}
\hline Measures & Loadings & Means & CR (AVE) \\
\hline Environment $(\alpha=0,847)$ & & & $0,908(0,767)$ \\
\hline The appearance of Digital Branch Mandiri Syariah visually attractive & 0,898 & 4.794 & \\
\hline The layout of the Digital Branch Mandiri Syariah feel comfortable & 0,900 & 4.738 & \\
\hline Digital Branch Mandiri Syariah in a convenient location & 0,828 & 4.687 & \\
\hline Frontline Personnel $(\alpha=0,866)$ & & & $0,918(0,789)$ \\
\hline The employees of the Digital Branch Mandiri Syariah are polite & 0,884 & 4.786 & \\
\hline The employees of Digital Branch Mandiri Syariah always help customers & 0,892 & 4.766 & \\
\hline The employees of Digital Branch Mandiri Syariah can find out what customers need & 0,861 & 4.710 & \\
\hline Moments-of-Truth $(\alpha=0,798)$ & & & $0,881(0,713)$ \\
\hline I appreciate the way Mandiri Syariah resolves problems faced by customers & 0,890 & 4.714 & \\
\hline Mandiri Syariah is flexible in solving problems faced by customers & 0,903 & 4.611 & \\
\hline Mandiri Syariah is sincere in solving problems faced by customers & 0,871 & 4.639 & \\
\hline Product Offerings $(\alpha=0,852)$ & & & $0.910(0,772)$ \\
\hline $\begin{array}{l}\text { Mandiri Syariah always provides the latest information regarding new services or products } \\
\text { to customers }\end{array}$ & 0,848 & 4.667 & \\
\hline Mandiri Syariah provides all Islamic banking products needed by customers & 0,852 & 4.532 & \\
\hline Mandiri Syariah offers a wide range of Islamic banking products and services & 0,833 & 4.675 & \\
\hline Attitude towards Islamic banking $(\alpha=0,797)$ & & & $0,865(0,617)$ \\
\hline Choosing Mandiri Syariah as an Islamic banking service is a good idea & 0,860 & 4.778 & \\
\hline I am happy to choose the services provided by Mandiri Syariah & 0,830 & 4.754 & \\
\hline $\begin{array}{l}\text { The majority of people who are important to me choose Islamic banking products from } \\
\text { Mandiri Syariah }\end{array}$ & 0,748 & 4.337 & \\
\hline My family members prefer Islamic banking services from Mandiri Syariah & 0,693 & 4.210 & \\
\hline Customer Satisfaction $(\alpha=0,870)$ & & & $0,911(0,720)$ \\
\hline I have a positive assessment of the Digital Branch Mandiri Syariah services & 0,828 & 4.750 & \\
\hline $\begin{array}{l}\text { I feel that the transaction using the Digital Branch Mandiri Syariah service is right and } \\
\text { suits my needs }\end{array}$ & 0,846 & 4.714 & \\
\hline Overall I am satisfied with Mandiri Syariah and the Digital Branch services provided & 0,851 & 4.702 & \\
\hline $\begin{array}{l}\text { Mandiri Syariah can provide Digital Branch services more than I need and that satisfies } \\
\text { me }\end{array}$ & 0,856 & 4.496 & \\
\hline Customer Loyalty $(\alpha=0,897)$ & & & $0,924(0,709)$ \\
\hline I feel I have a strong relationship with Mandiri Syariah & 0,841 & 4.448 & \\
\hline Mandiri Syariah will be my first choice to get Digital Branch service & 0,867 & 4.325 & \\
\hline I will not change the Digital Branch service to another bank in the near future & 0,871 & 4.563 & \\
\hline I will use more and more Digital Branch Mandiri Syariah services in the future & 0,815 & 4.563 & \\
\hline
\end{tabular}

Table 3. The Results of hypotheses test

\begin{tabular}{|lccccc|}
\hline & $\begin{array}{c}\text { Original } \\
\text { Sample } \\
(\mathrm{O})\end{array}$ & $\begin{array}{c}\text { Sample } \\
\text { Mean (M) }\end{array}$ & $\begin{array}{c}\text { Standard } \\
\text { Deviation } \\
(\text { STDEV) }\end{array}$ & $\begin{array}{c}\text { T Statistics } \\
(|\mathrm{O} / \mathrm{STDEV}|)\end{array}$ & $\begin{array}{c}\text { P } \\
\text { Values }\end{array}$ \\
\hline Attitude Towards Islamic Banking -> Customer Satisfaction & 0,392 & 0,394 & 0,068 & 5,723 & 0,000 \\
Customer Experience Quality -> Attitude Towards Islamic Banking & 0,742 & 0,745 & 0,030 & 24,541 & 0,000 \\
Customer Experience Quality -> Customer Loyalty & 0,337 & 0,336 & 0,116 & 2,905 & 0,004 \\
Customer Experience Quality -> Customer Satisfaction & 0,491 & 0,490 & 0,070 & 7,014 & 0,000 \\
Customer Satisfaction -> Customer Loyalty & 0,382 & 0,386 & 0,113 & 3,380 & 0,001 \\
Environment -> Customer Experience Quality & 0,289 & 0,289 & 0,014 & 21,168 & 0,000 \\
Frontline Personel -> Customer Experience Quality & 0,304 & 0,304 & 0,015 & 20,712 & 0,000 \\
Moments of Truth -> Customer Experience Quality & 0,285 & 0,284 & 0,013 & 21,900 & 0,000 \\
Product Offerings -> Customer Experience Quality & 0,288 & 0,287 & 0,014 & 21,221 & 0,000 \\
\hline
\end{tabular}




\section{CONCLUSIONS \& IMPLICATIONS}

In this research, it was found that in customer experience, the dimension that has the greatest influence is personal frontline. This dimension refers to customer assessments of communications and interactions with employees at branches. Employee interpersonal skills have the potential to influence customer experience so that they can create value and goal-oriented experiences in consumer behaviour [8], given that employee's interpersonal skills have the potential to influence the experience of creating value by interacting with customers [26] and goal oriented experiences in consumer behaviour. So customers who come to branches are customers who make transactions that cannot be done through mobile banking and still need to meet physically through the banking hall. Therefore, building a digital branch to provide customers with a phygital (physical-digital) experience is considered to be a bridge to branchless banking. Thus, the personal frontline factor plays an important role in shaping the customer experience. The frontline personnel who are helpful and polite, always help customers and know customer needs must be maintained and even improved the skill.

Customer Experience has the greatest influence on attitude toward Islamic banking. Such a causative relationship is possible on the grounds that attitudes towards Islamic banking can serve as a "halo effect" of customer experience and satisfaction with the service. In a study conducted by Inventure-Alvara, 58.8\% of respondents answered that with the pandemic, they prefer financial institutions with Islamic principles over conventional ones. Therefore, this momentum can be put to good use because the potential for the halal market and Islamic banking in Indonesia is very large.

Customer Experience has a positive and significant relationship with attitude towards Islamic Banking, customer satisfaction and customer loyalty. In Islam it teaches that you must convey information in truth, so satisfaction can be achieved because of the match between promise and reality. Implementing sharia principles is the right way to build relationships with customers, as well as build satisfaction and loyalty. Therefore, it would be better if companies build relationships with customers that are more emotional than those that are merely transactional. This can be enhanced by providing convenience in every customer transaction, namely paying attention to customers not for the sole interest of the bank but for meeting customer needs according to the personal frontline dimension. Pay attention to financial needs that are appropriate and related to the future of customers and their families can increase customer convenience in using banking services.
To face industrial development, Islamic banking must be adaptive to the development of digital technology. The Digital Branch which was initiated by Mandiri Syariah (now Bank Syariah Indonesia) is a form of innovation in Islamic banking to answer the challenges of digitalisation. Until now, banks have also begun to consider the development of open banking with the aim of providing increasingly complete digital services and facilities on their respective platforms. The development of omni-channel by presenting integrated services conventionally and digitally will also make customers more comfortable in making transactions. In addition, there is a need for integration of Islamic commercial and social finance. So it is necessary to build Islamic financial institutions from good to great with agile mindset.

\section{LIMITATIONS \& FUTURE RESEARCH}

The limitation this research is that related to the factors such as use of new technology. It needs to be examined for ease of use and acceptance of the risks of using new mechanisms such as opening an online account so that we can find out more about these two things from the side of banking customers. Then from a financial perspective it can still be explored again the impact of implementing digital branches by considering that this innovation can make business processes more effective and efficient so it's expected to increase business volume and profit for company in the future.

\section{AUTHORS' CONTRIBUTIONS}

Dwi Januar Luqmansyah is a researcher in this research and Mrs. Sri Rahayu Hijrah Hati provides guidance and direction in the process and findings of this research. All authors provide critical feedback and help shape research and analysis. This is useful for better research in the future.

\section{ACKNOWLEDGMENTS}

The research would not have been possible without the support of my lecturer, Mrs. Sri Rahayu Hijrah Hati, $\mathrm{Ph} . \mathrm{D}$. Her knowledge and attention to detail kept this research on track from beginning. 


\section{REFERENCES}

[1] State of the Global Islamic Economy 2020/21 Report. DOI: https://www.salaamgateway.com/reports/state-ofthe-global-islamic-economy-202021-report-englishexecutive-summary

[2] Survei Nasional Literasi dan Inklusi Keuangan Otoritas Jasa Keuangan. DOI: https://www.ojk.go.id/id/beritadan-kegiatan/publikasi/Pages/Survei-Nasional-Literasidan-Inklusi-Keuangan.aspx

[3] Mandiri Syariah (2019). Fokus Transformasi Digital Kinerja Mandiri Syariah tahun 2019. DOI: https://www.mandirisyariah.co.id/newsupdate/berita/fokus-transformasi-digital-kinerja-mandirisyariah-tahun-2019-tumbuh-melesat

[4] Payne, A., Frow, P. (2005) A Strategic Framework for Customer Relationship Management. Journal of Marketing, 69, 167-176.

[5] T Fernandez, T Pinto. (2019) Relationship quality determinants and outcomes in retail banking services: The role of customer experience. Journal of Retailing and Consumer Services 50, 30-41.

[6] Olavarría-Jaraba, A., Cambra-Fierro, J., Centeno, E., Vázquez-Carrasco, R., (2018). Relationship quality as an antecedent of customer relationship proneness: a cross cultural study between Spain and Mexico. J. Retail. Consum. Serv. 24, 60-69

[7] Kim, S., Cha, J., Knutson, B.J. and Beck, J.A. (2011), Development and testing of the Consumer Experience Index (CEI), Managing Service Quality: An International Journal, Vol. 21 No. 2, pp. 112-132

[8] Klaus, Ph. \& Maklan, S. (2012). EXQ: A multiple-scale for assessing service experience. Journal of Service Management, 23, 1 .

[9] Liljander, V. \& Strandvik, T. (1993). Estimating zones of tolerance in perceived service quality and perceived service value, International Journal of Service Industry Management, 4(2), 6-28

[10] Garg, R., Rahman, Z., Qureshi, M., 2014. Measuring customer experience in banks: scale development and validation. J. Model. Manag. 9 (1), 87-117.

[11] Lada, S., Tanakinjal, G.H. and Amin, H. (2009), Predicting intention to choose Halal products using theory of reasoned action, International Journal of Islamic and Middle Eastern Finance and Management, Vol. 2 No. 1, pp. 66-76.

[12] Usman, H, Nurdin Sobari, Emil Azman Sulthani (2019). Islamic Marketing Sebuah Pengantar. Depok: Raja Grafindo Persada.

[13] Parasuraman, A., Zeithaml, Valerie A., \& Malhotra, Arvind. (2005). E-S-QUAL: A multiple-item scale for assessing electronic service quality. Journal of Service Research, 7, 1-21
[14] Baran, R J., Galka, R. J., and Strunk, D. P. (2008). Principles of Customer Relationship Management. Mason, OH: Thomson South-Wester.

[15] Rowley, J. (2005). Building brand webs: Customer relationship management through the Tesco Clubcard loyalty scheme. International Journal of Retail \& Distribution Management.

[16] Jain, R \& Bagdare S (2017). Customer experience - a review and research agenda. Journal of Service Theory and Practice, 27 (3).

[17] Beckwith, N. E., \& Lehmann, D. R. (1975). The importance of halo effects in multi-attribute attitude models. Journal of Marketing Research, 12(3), 265-275. https://doi.org/10.2307/3151224

[18] Phillips, D.M. and Baumgartner, H. (2002) The Role of Consumption Emotions in the Satisfaction Response. Journal of Consumer Psychology, 12, 243-252. http://dx.doi.org/10.1207/S15327663JCP1203_06

[19] Rowley, J. (2005). Building brand webs: Customer relationship management through the Tesco Clubcard loyalty scheme. International Journal of Retail \& Distribution Management.

[20] Bowen \& Chen (2001). The relationship between customer satisfaction and customer loyalty. International Journal of Contemporary Hospitality Management 13(5):213-217. DOI: $\underline{10.1108 / 09596110110395893}$

[21] De Wulf, K.,Schroeder, Gaby (2011). Investments in consumer relationships: a critical reassessment and model extension. The International Review of Retail, Distribution and Consumer Research. Pages 245-261.

[22] Hair, Joseph E, Jr et al. (2014). A Primer on Partial Least Squares Structural Equation Modeeling (PLS-SEM). SAGE Publications,Inc. California. USA

[23] Malhotra, N. K. (2010). Marketing research: an applied orientation (14th). Upper Saddle River, NJ: Prentice Hall.

[24] LaSalle, D. and Britton, T.A. (2003) Priceless: Turning Ordinary Products into Extraordinary Experiences. Boston, MA, Harvard Business School Press.

[25] Oliver, Richard L., (1999). "Whence Consumer Loyalty", Journal of Marketing., Volume. 63 Special Issue, pp. 3344.

[26] Barari, M., Furrer, O., 2018. The customer experience ecosystem in two cultural contexts. J. Financ. Serv. Mark. 23 (3-4), 234-243. 